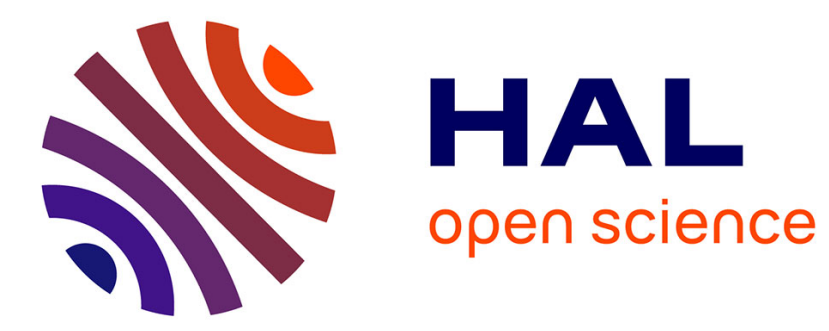

\title{
Self-esteem, self-confidence, anxiety and claimed self-handicapping: A mediational analysis
}

Guillaume R. Coudevylle, Christophe Gernigon, Kathleen Martin Ginis

\section{To cite this version:}

Guillaume R. Coudevylle, Christophe Gernigon, Kathleen Martin Ginis. Self-esteem, self-confidence, anxiety and claimed self-handicapping: A mediational analysis. Psychology of Sport and Exercise, 2011, 12, pp.670-675. 10.1016/j.psychsport.2011.05.008 . hal-01343259

\section{HAL Id: hal-01343259 \\ https://hal.univ-antilles.fr/hal-01343259}

Submitted on 8 Jan 2018

HAL is a multi-disciplinary open access archive for the deposit and dissemination of scientific research documents, whether they are published or not. The documents may come from teaching and research institutions in France or abroad, or from public or private research centers.
L'archive ouverte pluridisciplinaire HAL, est destinée au dépôt et à la diffusion de documents scientifiques de niveau recherche, publiés ou non, émanant des établissements d'enseignement et de recherche français ou étrangers, des laboratoires publics ou privés. 
Self-esteem, Self-confidence, Anxiety and Claimed Self-handicapping:

A Mediational Analysis

Guillaume R. Coudevylle

Université des Antilles et de la Guyane, France

Laboratoire Adaptation au Climat Tropical Exercice et Société (ACTES)

Christophe Gernigon

Université de Montpellier 1, France

Kathleen A. Martin Ginis

McMaster University, Canada

RUNNING HEAD: A MEDIATIONAL ANALYSIS OF SELF-HANDICAPPING

Submitted July $23^{\text {rd }} 2010$.

Guillaume R. Coudevylle, Maître de Conférences.

Université des Antilles et de la Guyane, France

Laboratoire Adaptation au Climat Tropical Exercice et Société (ACTES)

Adresse personnelle : 870 rue du Maréchal de Lattre de Tassigny, 62100 Calais

甶: $0603253921 \square$ : guillaumecoudevylle@hotmail.com/coudevg@mcmaster.ca

Christophe Gernigon, Maître de Conférences (HDR)

Université Montpellier 1

Faculté des Sciences du Sport et de l'Education Physique

UFR STAPS

Laboratoire Conduites Addictives, de Performance et Santé (EA 4206)

700, avenue du Pic Saint-Loup

34090 - Montpellier, France 용 : +33 (0)467415751

Fax : +33(0)4 67415708

$\bowtie$ : christophe.gernigon@univ-montp1.fr Website: www.performance-sante.fr

Kathleen Martin Ginis, Professor

McMaster University

Department of Kinesiology

Hamilton, Ontario, Canada, L8S 4K1.

$\bowtie:$ martink@mcmaster.ca 


\begin{abstract}
The purpose of the present study was to examine the mediational role of self-confidence and anxiety in the relationship between self-esteem and claimed self-handicapping in an achievement context. After hearing and reading about specific conditions of performing that were intended to favor invoking excuses for future poor performance, 68 competitive basketball players completed measures of self-esteem, anxiety (cognitive and somatic), self-confidence, and claimed self-handicapping. Then, they warmed-up and carried out a basketball task. Self-esteem negatively predicted cognitive anxiety and positively predicted self-confidence. In turn, selfconfidence negatively predicted claimed self-handicapping and mediated the relationship between self-esteem and claimed self-handicapping. Cognitive and somatic anxieties did not mediate the relationship between self-esteem and claimed self-handicapping. Together, these results suggest that individuals with low self-esteem use more claimed self-handicaps because they have lower self-confidence. These findings shed light on the psychological processes that lead people with low self-esteem to use strategies of claimed self-handicaps.
\end{abstract}

Keywords: Excuses, achievement context, social comparison, basketball 


\section{Self-esteem, Anxiety, Self-confidence, and Claimed Self-handicapping:}

\section{A Mediational Analysis}

Berglas and Jones (1978) defined self-handicapping as "any action or choice of performance setting that enhances the opportunity to externalize (or excuse) failure and to internalize (reasonably accept credit for) success" (p. 406). For example, if a self-handicapping person performs poorly, then the failure can be attributed to the performance impediment rather than the person's ability or competence. On the other hand, if the self-handicapping person performs well, then the athlete creates the impression of being especially competent and talented, because success was achieved despite obstacles. In addition, they may also internalize the augmented perceptions of competence (Baumeister, Tice, and Hutton, 1989).

\section{Self-Esteem and Self-Handicapping Strategies}

As noticed early by Jones and Berglas (1978), self-handicappers are legion in the sports world. Indeed, Rhodewalt (1990) mentioned that athletic and intellectual performance settings are particularly suited to examine self-handicapping in the face of evaluative threat and potentially self-damaging feedback. Field studies have been used to identify the antecedents of the use of self-handicaps prior to competitive or evaluated physical activity events (for reviews, see Coudevylle, Gernigon, Martin Ginis, \& Famose, 2010; Martin Ginis, Lindwall, \& Prapavessis, 2007; Prapavessis, Grove, \& Eklund, 2004). Self-esteem is one factor that has been studied as an antecedent. Self-esteem is the evaluation that individuals make and customarily maintain with regard to themselves. It expresses an attitude of approval or disapproval towards the self (Rosenberg, 1965).

Martin and Brawley (2002, Study 2) found that low self-esteem was associated with greater claimed self-handicapping prior to a fitness test. In another study examining the 
determinants of self-handicapping strategies in sport, Coudevylle, Martin Ginis, and Famose (2008a) showed that self-esteem was significantly negatively correlated with claimed selfhandicapping. Indeed, several authors have suggested that low self-esteem individuals are likely to self-handicap more frequently than high self-esteem individuals (Martin \& Brawley, 2002; Prapavessis \& Grove, 1998; Snyder \& Higgins, 1988) because low self-esteem individuals encounter more situations where they doubt their ability to be successful. Thus, self-confidence may be a more proximal factor than self-esteem when predicting claimed self-handicapping use.

\section{Self-Esteem, Self-Handicapping Strategies and Potential Mediators}

Although several studies have examined the direct relationships between self-esteem and claimed self-handicapping, little is known about the psychological processes that mediate these relationships. In their review of the self-handicapping literature, Arkin and Oleson (1998) suggested that the combined influence of state and trait beliefs about the self could be an important area of investigation for self-handicapping researchers. In the present study, we focused on the state beliefs of anxiety and self-confidence, and the trait belief of self-esteem. State anxiety is a psychological (i.e., cognitive anxiety) and physical (i.e., somatic anxiety) response to a threat to the self-concept, characterized by subjective, consciously perceived feelings of tension (Spielberger, 1970). In athletes, self-confidence is an athlete's belief or degree of certainty that he or she has the ability to perform successfully in sport (Vealey, 2004).

It seems plausible that the use of claimed self-handicapping may be also linked to situation-specific high anxiety or low levels of self-confidence. On the one hand, some studies have shown that trait self-esteem correlates negatively with scores on measures of manifest anxiety and social anxiety (e.g., Leary \& Kowalski, 1995). This has been supported by Suliman and Halabi (2007) who showed that self-esteem is negatively correlated with state anxiety (i.e., 
cognitive and somatic anxieties) and self-confidence among baccalaureate nursing students. That said, because self-esteem reflects thoughts about the self, it makes sense that self-esteem would be more related to negative thoughts or concerns about performance (i.e., cognitive anxiety) and not with perceived bodily symptoms of competitive anxiety (i.e., somatic anxiety). On the other hand, self-esteem was found to positively relate to self-confidence (Campbell, 1990, Study 1). Indeed, people with low self-esteem want to succeed as much as people with high self-esteem but they are simply less confident that they will be able to do so (McFarlin \& Blascovich, 1981).

Much has been written about the role of ability uncertainty (e.g., Berglas \& Jones, 1978) and threat to self-esteem as predictors of self-handicapping (Snyder \& Smith, 1982). In sport contexts, for instance, trait competitive anxiety (Martens, Vealey, \& Burton, 1990) was found to positively relate to situational manifestations of claimed self-handicapping (Ferrand, Champely, \& Brunel, 2005) and state competitive anxiety was found to positively relate to trait measures of self-handicapping (Prapavessis \& Grove, 1994; Prapavessis, Grove, Maddison, \& Zillmann, 2003). Furthermore, Ryska, Yin, and Cooley (1998) showed that athletes' reports of performancedebilitating obstacles prior to competition were positively correlated with their states of cognitive anxiety (negative concerns about performance) and somatic anxiety (perceived bodily symptoms of competitive anxiety), and negatively correlated with their state of self-confidence. In addition, Kuczka and Treasure (2005) found that claimed situational self-handicapping was positively correlated with self-efficacy, a construct that is conceptually close to self-confidence (Bandura, 1997).

Given the links that exist between self-esteem and cognitive anxiety and self-confidence on the one hand, and between states of anxiety and self-confidence and claimed selfhandicapping on the other hand, it seems worthwhile to examine the role of cognitive anxiety and self-confidence as potential mediators of the relationship between self-esteem and claimed self- 
handicapping. Thus, the purpose of the present study was to examine these mediated relationships in a sport setting, since sport is an achievement context that is propitious to self-handicapping (Jones \& Berglas, 1978). We examined the mediational relationships among athletes performing a basketball task. It was predicted that the negative relationship between self-esteem and claimed self-handicapping would be mediated by cognitive anxiety and self-confidence.

\section{Method}

\section{Participants}

Participants were 68 competitive basketball players, 34 men $\left(M_{\mathrm{age}}=21\right.$ years; $\left.S D=4.5\right)$ and 34 women $\left(M_{\text {age }}=19.5\right.$ years; $\left.S D=3.9\right)$. To ensure that participants would be personally invested in the experimental task and its outcome, all players competed at the French regional level—a sufficiently competitive level. Participants were recruited from eight different teams. Note that the data from 56 participants represent a secondary analysis of data previously published (Coudevylle, Martin Ginis, Famose, \& Gernigon, 2009).

\section{Measures}

General Self-esteem. Vallières and Vallerand's (1990) French version of Rosenberg's (1965) Self-Esteem Scale was used to measure general self-esteem. This scale includes 10 items capturing a continuum of self-worth statements. The original scale has been used extensively for research in samples with a variety of ages, nationalities, and socioeconomic levels (Rosenberg, 1965) and has demonstrated consistently acceptable internal consistency reliability (coefficient alphas of 0.72-0.87; Wiley, 1989). Each item was answered on a four-point Likert-type scale (1 $=$ strongly disagree; $4=$ strongly agree) .

Cognitive Anxiety, Somatic Anxiety, and Self-confidence. State anxiety and selfconfidence were measured using Cury, Sarrazin, Peres, and Famose's (1999) French version of the Competitive State Anxiety Inventory - 2 (CSAI-2; Martens et al., 1990). This questionnaire, 
which was found to be reliable and valid for French athletes, consists of seven items measuring cognitive anxiety, seven items measuring somatic anxiety and nine items measuring selfconfidence. According to Martens and colleagues, cognitive anxiety is conceptualized as negative expectations of success and cognitive concerns about oneself; somatic anxiety is conceptualized as the perception of one's physiological arousal; and self-confidence is conceptualized as one's belief in meeting the challenge of the task to be performed. Participants indicated the extent to which they were currently experiencing the content of each item using a Likert-type scale ranging from 1 (not at all) to 4 (completely). The questionnaire has been extensively utilized in sport settings and possesses strong reliability and validity (Martens et al., 1990).

Claimed Self-handicapping. A scale that was adapted from that used by Martin and Brawley (2002, Study 2) was used to measure claimed self-handicapping. Whereas Martin and Brawley's scale consisted of just seven possible impediments, our scale consisted of thirteen impediments that athletes may use as self-handicaps such as: "I am feeling tired," "I have personal concerns in this moment". These impediments were chosen because they were those most frequently cited by athletes in Carron and colleagues' studies of self-handicapping in sport (Carron, Prapavessis, \& Grove, 1994; Hausenblas \& Carron, 1996). In addition, the participants were presented with a fourteenth, open-ended item that provided them with the opportunity to list any other potential impediments to their performance. For each item, participants indicated (a) whether the impediment was present (yes/no), and (b) the extent to which each impediment would interfere with their performance (i.e., perceived impact), using a Likert-type scale ranging from 0 (not at all) to 6 (extremely). A score of claimed self-handicapping was calculated by considering the items to which the participants had answered "yes" and by adding the impact scores for these items. Higher scores were indicative of greater claims of performance impediments and, consequently, greater claimed self-handicapping. This measure has been used 
in previous studies involving competitive athletes (Coudevylle et al., 2008a; Coudevylle, Martin Ginis, Famose, \& Gernigon, 2008b; Coudevylle, et al., 2009; Kuczka \& Treasure, 2005).

Construct validity for this way of measuring self-handicapping has been supported by studies showing significant correlations between the claimed impact of performance impediments and theoretically linked constructs such as self-presentational efficacy (Martin \& Brawley, 2002), self-esteem, and performance self-efficacy (Coudevylle et al., 2008a; Martin \& Brawley, 2002). Internal consistency is not an appropriate psychometric index for this type of self-handicapping measure because athletes are not expected to respond similarly to all of the items on the scale. Indeed, when athletes use claimed self-handicapping, they typically cite only one or two performance impediments. It is unusual for an athlete to cite several claimed self-handicaps, probably because a single self-handicapping claim is sufficient to protect an athlete's image, and the use of multiple self-handicaps could have considerable self-presentational liabilities. Thus, a reliability coefficient was not calculated or reported.

\section{Experimental Task}

After having completed measures of self-esteem, anxiety (cognitive and somatic), selfconfidence, and claimed self-handicapping, participants then warmed-up and carried out a basketball task. This task was the same as that used in previous experimental designs intended to investigate self-handicapping (Coudevylle et al., 2008a, 2008b, 2009) and consisted of completing three repetitions of an obstacle course laid out on a standard basketball court.

\section{Procedure}

The experiment was conducted in the athletes' usual training hall and during a regularly scheduled training session. To maximize the likelihood of self-handicapping, the experimental context was designed to enhance the salience of known antecedents of self-handicapping (for a review, see Prapavessis et al., 2004; Self, 1990). Specifically, the situation emphasized results, 
comparisons of one's own performance relative to others' (e.g., Ames \& Archer, 1988), public awareness of the use of self-handicaps and a public performance (Elliot, Cury, Fryer, \& Huguet, 2006). The experimenter told the participants that their results would be compared with those of their teammates and would be also used to rank the players of the region.

After hearing and reading about the conditions in which the test would be performed, participants completed the measures of self-esteem, anxiety, and self-confidence. At this time, participants did not know that they would have the opportunity to self-handicap. Then, they completed the measure of claimed self-handicapping on another sheet. In order to mask the true purpose of the self-handicapping questionnaire, the experimenter told the participants:

"The following questionnaire is intended to know your general actual state in order to interpret your results today. It will allow those who will evaluate your competence (the experimenter, your trainer, the other players, the spectators) to consider your current personal situation when authenticating your results and comparing them with those of the other participants."

After completing the claimed self-handicapping measure, participants then warmed-up and completed the task. They performed the test in the presence of the experimenter, spectators (i.e., player's parents and friends), coaches and other players. Spectators, coaches and the other players were present only to observe and support the tested player while the experimenter scored his or her performance. Once the participants had completed the task, they were debriefed regarding the true purpose of the study. Then, the first author provided each team with a lecture about self-handicapping and led a discussion about this strategy and its consequences. The procedure was similar to that employed in previous studies of self-handicapping (see Coudevylle et al., 2008a; 2008b, 2009).

\section{Analyses}


The three-step procedure advocated by Baron and Kenny (1986) was used to test the assumed mediating roles of anxiety and self-confidence in the relation between self-esteem and claimed self-handicapping. First, each potential mediator (cognitive and somatic anxieties, selfconfidence) was regressed on the independent variable (self-esteem). Second, the dependent variable (claimed self-handicap) was regressed on each potential mediator. Third, the dependent variable was regressed on both the independent variable and each potential mediator. There is a mediating effect of a potential mediator if significant links are found at the first two steps and if the relation between the independent variable and the dependent variable is no longer significant (perfect mediation) or is reduced (partial mediation) when the mediator is introduced into the equation (third step). In addition, the significance of the mediated effect was calculated using a Sobel test.

\section{Results}

To test the direct relationship between self-esteem and claimed self-handicapping, claimed self-handicapping was regressed on self-esteem. A significant overall model $[F(1,66)=$ $\left.9.32, p<.01, R^{2}=.12\right]$ was found and self-esteem was a significant negative predictor of claimed self-handicapping $(\beta=-.35, p<.01)$.

To test the relationship between self-esteem and the potential mediators, each potential mediator was regressed on self-esteem. Regressing cognitive anxiety on self-esteem yielded a significant effect $\left[F(1,66)=9.32, p<.01, R^{2}=.12\right]$. Self-esteem was a significant negative predictor of cognitive anxiety $(\beta=-.35, p<.01)$. Regressing somatic anxiety on self-esteem did not yield a significant effect $\left[F(1,66)=3.73, p>.05, R^{2}=.05\right]$. Regressing self-confidence on self-esteem yielded a significant effect $\left[F(1,66)=18.92, p<.001, R^{2}=.22\right]$. Self-esteem was a significant positive predictor of self-confidence $(\beta=.47, p<.001)$. 
Finally, the relationship between self-esteem and claimed self-handicapping was tested again with the influence of each remaining potential mediator controlled (i.e., cognitive anxiety and self-confidence). Regressing claimed self-handicapping on both cognitive anxiety and selfesteem yielded a significant effect $\left[F(2,65)=4.6, p<.05, R^{2}=.12\right]$. Self-esteem significantly negatively predicted self-handicapping $(\beta=-.34, p<.01)$ but cognitive anxiety did not. Regressing claimed self-handicapping on both self-confidence and self-esteem yielded a significant effect $\left[F(2,65)=8.04, p<.001, R^{2}=.19\right]$. Self-confidence significantly negatively predicted claimed self-handicapping $(\beta=-.30, p<.05)$, whereas self-esteem did not. To summarize, self-confidence, but not cognitive anxiety, was found to mediate the relationship between self-esteem and claimed self-handicapping (see Figure 1). To check the significance of the mediated effect, a Sobel test was conducted whereby the products of the unstandardized regression coefficients of Paths $\mathrm{B}(\mathrm{B}=.68)$ and $\mathrm{C}(\mathrm{B}=-.26)$ were divided by a standard error term $^{1}$ (i.e., $\mathrm{z}$ score). The Sobel test was significant $(\mathrm{z}$ score $=-2.78, p<.05)$.

\section{Discussion}

The purpose of the present study was to examine the role of state anxiety and selfconfidence as potential mediators of the relationship between self-esteem and claimed selfhandicapping. First, when considered as the sole predictor variable, self-esteem was a significant negative predictor of claimed self-handicapping. Consistent with our hypotheses, this finding replicates results from previous studies that also addressed the relationship between self-esteem and claimed self-handicapping in sport and exercise settings (Coudevylle et al., 2008a; Martin \& Brawley, 2002, Study 2). This finding is also consistent with results that were observed in an academic context (Snyder \& Higgins, 1988).

\footnotetext{
${ }^{1} \mathrm{z}$ score $=a b / \sqrt{\left(b^{2} s a^{2}+a^{2} s b^{2}+s a^{2} s b^{2}\right)}$, where $a$ and $b$ are unstandardized regression coefficients for the regression of the mediator on the predictor, and the outcome on the mediator, respectively, while $s a$ and $s b$ are their respective standard errors.
} 
Second, self-esteem was found to negatively predict cognitive anxiety but not somatic anxiety. These results are consistent with several studies showing that trait self-esteem correlates negatively with scores on measures of social anxiety (e.g., Leary \& Kowalski, 1995) and state anxiety (Suliman \& Halabi, 2007). Likewise, these results are in agreement with our expectations that self-esteem would be more related to cognitive anxiety (i.e., negative thoughts or concerns about performance) than with somatic anxiety (i.e., perceived bodily symptoms of competitive anxiety). Indeed, this result makes sense given that self-esteem reflects thoughts about the self; such thoughts should be more strongly linked with thoughts about one's performance than perceptions of somatic symptoms. The relationship between self-esteem and cognitive anxiety was negative because participants with low self-esteem have more concerns about performance (i.e., cognitive anxiety) than participants with high self-esteem. It is also noteworthy that selfesteem was a significant positive predictor of self-confidence. This finding corroborates previous research (e.g., Campbell, 1990, Study 1).

The negative relationship between self-esteem and claimed self-handicapping was in fact mediated by self-confidence. Consistent with our hypotheses, this finding complements results from previous research which showed that athletes' reports of performance-debilitating obstacles prior to competition were negatively correlated with their state of self-confidence (Ryska et al., 1998). As a result, self-esteem and self-confidence may no longer be seen as two independent predictors of claimed self-handicapping. Rather, the present research shows that self-confidence may be considered the process through which self-esteem influences claimed self-handicapping. This finding is of importance since it reveals self-confidence as the most proximal determinant of claimed self-handicapping, compared to self-esteem.

Contrary to our expectations, the negative relationship between self-esteem and claimed self-handicapping was not mediated by state anxiety. More accurately, cognitive anxiety did not 
predict claimed self-handicapping, a result inconsistent with previous research showing positive relationships between claimed self-handicapping and both cognitive and somatic anxieties (Ryska et al., 1998). A possible explanation would be that that self-confidence is a factor stronger than cognitive anxiety for determining claimed self-handicapping prior to athletic tests. In addition, previous research has led some authors to consider that people use self-handicapping strategies to reduce their anxiety. For example, Coudevylle et al. (2008b) showed that athletes with a greater propensity to use claimed self-handicapping reported greater increases in perceptions of cognitive anxiety as facilitating their performance before the completion of an evaluative sport task. Therefore, while it can be hypothesized that the more anxious the individuals are in a given situation, the more they are prone to use self-handicapping (positive relationship), it can also be hypothesized that the more they plan to use self-handicapping, the less they may feel anxious (negative relationship). These opposite effects might thus nullify each other and result in an apparent absence of relationship between anxiety and self-handicapping.

Overall, the present research demonstrated that, among factors examined, self-confidence was the unique situational mediator of the relationship between self-esteem and claimed selfhandicapping in the sport context. In other words, one reason individuals with high self-esteem use less self-handicapping claims is because they have more self-confidence. Several authors have suggested that low self-esteem individuals are likely to self-handicap more frequently than high self-esteem individuals because low self-esteem individuals encounter more situations where they doubt their ability to be successful (Martin \& Brawley, 2002; Prapavessis \& Grove, 1998; Snyder \& Higgins, 1988). The present study demonstrated that this perspective is correct and showed that self-confidence is a better factor to determine claimed self-handicapping use than self-esteem. To conclude, by showing the meditational effect of self-confidence in the relationship between self-esteem and self-handicapping, our study sheds light on the very 
psychological processes that lead people with low self-esteem to use strategies of claimed selfhandicapping.

Despite these contributions, there are some limitations that warrant mentioning. The present research demonstrated that, of the variables we measured, self-confidence was the unique situational mediator of the relationship between self-esteem and claimed self-handicapping in a sport context. However, other factors that we did not examine could also mediate this relationship (e.g., self-efficacy, mastery-approach goals). For example, because self-efficacy is more specific to the task at hand than self-confidence, it could be a potent mediator of the self-esteem - selfhandicapping relationship. We recommend that future research examine this possibility.

From an applied perspective, given that athletes with high self-confidence do not use claimed self-handicapping, our results suggest that coaches, sport psychologists, and other interventionists should endeavour to promote strong self-confidence among their athletes. Not only is self-confidence (or self-efficacy) important for success (e.g., Bandura, 1997; Hollenbeck \& Hall, 2004; Vealey, 2004), but as the observed mediation between self-esteem and claimed self-handicapping indicates, self-confidence is also important for avoiding the use of claimed self-handicapping. Indeed, even if self-handicapping has any short-term benefits on performance (Bailis, 2001), the use of self-handicaps has detrimental long-term effects on well-being (Eronen, Nurmi and Salmela-Aro, 1998). 


\section{References}

Ames, C. A., \& Archer, J. (1988). Achievement goals in the classroom: Students' learning strategies and motivation processes. Journal of Educational Psychology, 80, 260-267.

Arkin, R. M., \& Oleson, K. C. (1998). Self-handicapping. In J. M. Darley \& J. Cooper (Eds.), Attribution and social interaction. The legacy of Edward E. Jones (pp. 313-371). Washington, DC: American Psychological Association.

Bailis, D. (2001). Benefits of self-handicapping in sport: A field study of university athletes. Canadian Journal of Behavioural Science, 33, 213-223.

Bandura, A. (1997). Self-efficacy: The exercise of control. New York: Freeman.

Baron, R. M., \& Kenny, D. A. (1986). The moderator-mediator variable distinction in social psychological reaseach: Conceptual, strategic, and statistical considerations. Journal of Personality and Social Psychology, 51, 1173-1182.

Baumeister, R. F., Tice, D. M. \& Hutton, D. G. (1989). Self-presentational motivations and personality differences in self-esteem. Journal of Personality, 57, 547-579.

Berglas, S., \& Jones, E. E. (1978). Drug choice as a self-handicapping strategy in response to non contingent success. Journal of Personality and Social Psychology, 36, 405-417.

Campbell, J. D. (1990). Self-esteem and clarity of the self-concept. Journal of Personality and Social Psychology, 59, 538-549.

Carron, A. V., Prapavessis, H., \& Grove, J. R. (1994). Group effects and self-handicapping. Journal of Sport \& Exercise Psychology, 16, 246-257.

Coudevylle, G. R., Martin Ginis, K. A., \& Famose, J.-P. (2008a). Determinants of selfhandicapping strategies in sport and their effects on athletic performance. Social Behavior and Personality, 36, 391-398. 
Coudevylle, G. R., Martin Ginis, K. A., Famose, J.-P., \& Gernigon, C. (2008b). Effects of selfhandicapping strategies on anxiety prior to athletic performance. The Sport Psychologist, 22, 304-315.

Coudevylle, G. R., Martin Ginis, K. A., \& Famose, J.-P., \& Gernigon, C. (2009). An experimental investigation of determinants and consequences of self-handicapping strategies across motivational climates. European Journal of Sport Science, 9, 219-227.

Coudevylle, G. R., Gernigon, C., Martin Ginis, K. A., \& Famose, J.-P. (2010). Les stratégies d'auto-handicap: Caractéristiques, déterminants et conséquences. Illustrations dans le domaine du sport [Self-handicapping strategies: Characteristics, determinants, and consequences. Illustrations in the domain of sport and exercise]. Manuscript submitted for publication.

Cury, F., Sarrazin, P., Peres, C., \& Famose, J.-P. (1999). Mesurer l'anxiété du sportif en compétition : Présentation de l'échelle d'état d'anxiété en compétition (EEAC) [Measuring athletes' anxiety in competition: Presentation of the Competitive State Anxiety Scale (CSAS)]. In C. Le Scanff et J.-P. Famose (Eds.), La gestion du stress [The management of stress]. Paris: Editions Revue EPS n ${ }^{\circ} 43$.

Elliot, A. J., Cury, F., Fryer, J. W., \& Huguet, P. (2006). Achievement goals, self-handicapping, and performance attainment: A mediational analysis. Journal of Sport \& Exercise Psychology, 28, 344-361.

Eronen, S., Nurmi, J.-E., \& Salmela-Aro, K. (1998). Optimistic, defensive-pessimistic, impulsive and self-handicapping strategies in university environments. Learning and instruction, 8, $159-177$. 
Ferrand, C., Champely, S., \& Brunel, P. C. (2005). Relations between female students' personality traits and reported handicaps to rhythmic gymnastics performance. Psychological Reports, 96, 361-373.

Hausenblas, H. A., \& Carron, A. V. (1996). Group cohesion and self-handicapping in female and male athletes. Journal of Sport \& Exercise Psychology, 18, 132-143.

Hollenbeck, G. P., \& Hall, D. T. (2004). Self-confidence and leader performance. Organizational Dynamics, 33, 254-269.

Jones, E. E., \& Berglas, S. (1978). Control of attributions about the self through selfhandicapping strategies: The appeal of alcohol and the role of underachievement. Personality and Social Psychology Bulletin, 4, 200-206.

Kuczka, K. K., \& Treasure, D. C. (2005). Self-handicapping in competitive sport: Influence of the motivational climate, self-efficacy, and perceived importance. Psychology of Sport and Exercise, 6, 539-550.

Leary, M. R., \& Kowalski, R. M. (1995). Social anxiety. New York: Guilford Press.

Leary, M. R., \& Shepperd, J. A. (1986). Behavioral self-handicapping vs. self-reported handicaps: A conceptual note. Journal of Personality and Social Psychology, 51, 12651268.

Martens, R., Vealey, R. S., \& Burton, D. (1990). Competitive anxiety in sport. Champaign, IL: Human Kinetics Publishers.

Martin, K. A., \& Brawley, L. R. (2002). Self-handicapping in physical achievement settings: The contributions of self-esteem and self-efficacy. Self and Identity, 1, 337-351.

Martin Ginis, K. A., Lindwall, M., \& Prapavessis, H. (2007). Who care what other people think? Self-presentation in exercise and sport. In G. Tenenbaum \& R. Eklund (Eds.), Handbook of Sport Psychology, 3rd ed. (pp. 136-159). Wiley publishers. 
McFarlin, D.B., \& Blascovich, J. (1981). Effects of self-esteem and performance feedback on future affective preferences and cognitive expectations. Journal of Personality and Social Psychology, 40, 521-531.

Prapavessis, H., \& Grove, J. R. (1994). Personality variables as antecedents of precompetitive mood state temporal patterning. International Journal of Sport Psychology, 25, 347-365.

Prapavessis, H., \& Grove, J. R. (1998). Self-handicapping and self-esteem. Journal of Applied Sport Psychology, 10, 175-184.

Prapavessis, H., Grove, J. R., \& Eklund, R. C. (2004). Self-presentational issues in competition and sport. Journal of Applied Sport Psychology, 16, 19-40.

Prapavessis, H., Grove, J. R., Maddison, R., Zillmann, N. (2003). Self-handicapping tendencies, coping, and anxiety responses among athletes. Psychology of Sport and Exercise, 4, 357375.

Rosenberg, M. (1965). Society and the adolescent self-image. Princeton, NJ: Princeton University Press.

Ryska, T. A., Yin, Z. N., \& Cooley, D. (1998). Effects of trait and situational self-handicapping on competitive anxiety among athletes. Current Psychology, 17, 48-56.

Self, E. A. (1990). Situational influences on self-handicapping. In R. L. Higgins, C. R. Snyder, \& S. Berglas (Eds.), Self-handicapping: The paradox that isn't? (pp. 37-68). New York: Plenum Press.

Snyder, C. R., \& Higgins, R. L. (1988). Excuses: Their effective role in the negotiation of reality. Psychological Bulletin, 104, 23-35.

Snyder, C. R., \& Smith, T. W. (1982). Symptoms as self-handicapping strategies: The virtues of old wine in a new bottle. In G. Weary (Eds.), Integrations of Clinical and Social Psychology (pp. 104-127). New York: Oxford University Press. 
Spielberger, C. (1970). The State-Trait Anxiety Inventory. New-York: Academic Press.

Suliman, W. A., \& Halabi, J. (2007). Critical thinking, self-esteem, and state anxiety of nursing students. Nurse Education Today, 27, 162-168.

Vallières, E., \& Vallerand, R. J. (1990). Traduction et validation canadienne-française de l'échelle de l'estime de soi de Rosenberg. International Journal of Psychology, 25, 305316.

Vealey, R. S. (2004). Self-confidence in athletes. Encyclopedia of Applied Psychology, 361-368.

Wiley, R. C. (1989). Measures of self-concept. Lincoln, NE: University of Nebraska Press. 
Appendix

A1. I am ill (e.g., flu, nauseous).

If so, how much did illness harm your performance?

A2. I have stomach problems (e.g., indigestion, eating too much or not enough).

If so, how much did your stomach problems harm your performance?

A3. I have physical problems (e.g., injury, aches, cramps).

If so, how much did your physical problems harm your performance?

A4. I am feeling tired (e.g., fatigued, lack of sleep).

If so, how much did feeling tired harm your performance?

A5. I have personal concerns at the moment (e.g., family, work).

If so, how much did those personal issues harm your performance?

A6. I am feeling good (reverse-scored).

If so, how much did feeling good help your performance?

A7. I have a lot going on at the moment (e.g., going out with friends, work).

If so, how much did having so much going on harm your performance?

A8. The test conditions do not suit me (e.g., evaluation method, time of day). 
If so, how much did the test conditions harm your performance?

A9. The test is not important to me.

If so, how much did this lack of importance harm your performance?

A10. I am not feeling well mentally (e.g., stressed, anxious).

If so, how much did your mental state harm your performance?

A11. I am not sufficiently prepared for the test (e.g., lack of practice/training).

If so, how much did your lack of preparation harm your performance?

A12. I recently drank alcohol and/or used drugs.

If so, how much did having consumed alcohol/drugs harm your performance?

A13. I am approaching the test under the best conditions (reverse-scored).

If so, how much did those conditions help your performance?

A14. Were there other issues/ circumstances which were not mentioned in the preceding list but which harmed your performance?

If so, what were those issues/circumstances, and how much did each harm your performance? 